\title{
Audit Fees, Kinerja Keuangan dan Risiko Perusahaan yang Melakukan Revaluasi Aset: Investigasi Berdasarkan Sektor Industri Manufaktur
}

\author{
Rima Auliyamartha Agustina ${ }^{1}$, Darmansyah $^{2}$ \\ ${ }^{1.2}$ Universitas Pancasila, Jl. Srengseng Sawah, Jagakarsa, Jakarta Selatan, 12640
}

\section{INFO ARTIKEL}

JEL Classsification:

L60

Keywords: asset revaluation, audit fees, return on asset, debt asset ratio.

\begin{abstract}
The revaluation of fixed assets is still not widely applied by the issuers in Indonesia, although the adoption of IFRS has been implemented since 2012. Assets revaluation is done in order for the company to calculate its fixed assets based on fair value so that the financial statements show the actual capability of the company. Factors related to the revaluation in addition to the cost of the appraiser's services are audit fees, financial performance and corporate risk. The purpose of this study is to see differences in audit fees, financial performance of manufacturing companies reflected by return on assets and debt to assets ratio based on industrial sector in companies that do asset revaluation. The analytical method used is Kruskal-Wallis Test. The results of this study indicate that there are differences in audit fees, return on assets and debt to assets ratios based on industry sectors in companies that perform asset revaluation.
\end{abstract}

\section{A B S T R A K}

Revaluasi aset tetap masih belum banyak diterapkan oleh para emiten di Indonesia, meskipun pengadopsian IFRS sudah diterapkan sejak tahun 2012. Penilaian kembali atau revaluasi aset dilakukan dengan tujuan agar perusahaan dapat melakukan perhitungan atas aset tetapnya berdasar nilai wajar sehingga laporan keuangan menunjukkan kemampuan perusahaan yang sebenarnya. Faktor-faktor yang berhubungan dengan revaluasi selain biaya jasa penilai adalah audit fees, kinerja keuangan dan risiko perusahaan. Tujuan penelitian ini adalah untuk melihat perbedaan audit fees, kinerja keuangan perusahaan manufaktur yang dicerminkan dengan return on assets dan debt to assets ratio berdasarkan sektor industri pada perusahaan yang melakukan revaluasi aset. Metode analisis yang digunakan adalah uji beda Kruskal-Wallis Test. Hasil penelitian tersebut menunjukkan bahwa terdapat perbedaan dalam audit fees, return on assets dan debt to assets ratio berdasarkan sektor industri pada perusahaan yang melakukan revaluasi aset.

*Email Korespondensi: 'atha.martha84@gmail.com,2darmansyah@univpancasila.ac.id 


\section{Pendahuluan}

IFRS menekankan penerapan konsep nilai wajar yang berdampak terhadap laporan keuangan dan kinerja keuangan perusahaan. Dampak yang ditimbulkan terdapat perbedaan pengukuran nilai dalam laporan keuangan yang sebelumnya menggunakan historical cost. Dengan adanya IFRS diharapkan dapat memberikan dampak terhadap kinerja keuangan peusahaan. Kinerja keuangan perusahaan dapat diukur dengan berbagai macam alat analisis, salas satunya dengan rasio keuangan. Mengapa model revaluasi aset menjadi sangat penting dalam meningkatkan kinerja keuangan karena mencerminkan nilai yang sebenarnya (fair value) atas aset tetap perusahaan. Revaluasi Penilaian kembali atas aset tetap perusahaan dilakukan berdasar dengan nilai pasar aset tetap yang berlaku dan ketika melakukan revaluasi ditetapkan oleh jasa ahli atau appraiser yang diakui oleh Pemerintah.

Penelitian mengenai model revaluasi aset pada perusahaan go public di Indonesia yang dilakukan oleh Hastoni (2013), menunjukkan sampai tahun 2012 masih sedikit perusahaan yang melakukan revaluasi. Penyebabnya yakni belum selarasnya standar akuntansi keuangan dan peraturan perpajakan di Indonesia. Penawaran yang diberikan pemerintah pada Paket Kebijakan V pada Oktober 2015 merupakan salah satu upaya untuk mendongkrak keinginan perusahaan melakukan penerapan model revaluasi. Jika sebelumnya perusahaan dikenakan pajak PPH 10\% untuk kenaikan nilai aset, maka sekarang pajak dipangkas menjadi 3-6\% saja. Kebijakan ini diatur dalam Peraturan Menteri Keuangan (PMK) nomor 191/PMK.010/2015 tentang penilaian kembali aktiva tetap dengan tujuan agar perusahaan yang sebelumnya tidak melakukan revaluasi atas aset tetapnya diharapkan dengan penurunan tarif PPH tersebut dapat melakukan revaluasi aset.

Penelitian terdahulu oleh Ahmar (2016) yang menginvestigasi 434 emiten sejak tahun 2012 sampai dengan 2014 memberikan hasil mengejutkan sebagai dampak dari implementasi penerapan IFRS. Faktanya, tidak lebih dari 10 persen emiten melakukan dan melaporkan revaluasi aset. Menurut Ahmar (2016) bahwa terdapat perbedaan auditfees emiten yang diaudit KAP Big 4 dan KAP Non-Big 4. Hasilnya emiten yang melakukan revaluasi aset dan diaudit KAP Big 4 dari tahun 2012 sampai dengan 2013 mengalami peningkatan, namun menurun di tahun 2014. Berbeda dengan emiten yang diaudit KAP Non-Big 4 mengalami peningkatan pada akhir 2014. Berdasar hasil tersebut menjelaskan audit fees yang mengalami peningkatan seiring aktivitas revaluasi seharusnya tidak menjadi penghambat untuk menerapkan model revaluasi aset. Munculnya biaya keagenan sebagai akibat dari revaluasi sendirinya akan tertutup oleh keuntungan atas nilai wajar.

Kappa (2009) meneliti hubungan antara revaluasi aktiva tetap dengan analisis return on investment (ROI) dan return on assets (ROA). Penelitiannya dilakukan pada 10 perusahaan manufaktur terdaftar di BEI dan melakukan revaluasi aktiva tetap tahun 2016. Hasil penelitian mengindikasikan pemberlakuan kebijakan revaluasi aktiva tetap tidak akan berdampak pada ROI dan ROA. Namun hasilnya berbeda dengan penelitian Aboody et al. (1999) Dimitropoulos et al. (2013), Yao et al. (2014) penelitiannya menunjukkan bahwa revaluasi aset berhubungan signifikan terhadap return on assets (ROA). Revaluasi aktiva tetap berakibat kuat terhadap komponen total aktiva, dikarenakan pada umumnya aktiva tetap mempunyai nilai yang relatif lebih besar dibandingkan dengan komponen aktiva lainnya sehingga hal ini akhirnya berdampak terhadap total aktivanya.

Berdasarkan adanya Peraturan Menteri Keuangan tersebut maka isu penting yang diakibatkan adalah aktivitas revaluasi aset, terutama untuk perusahaan-perusahaan manufaktur sektor industri tersebut menuntut kepemilikan aset tetap untuk aktivitas produksi dan non produksi. 


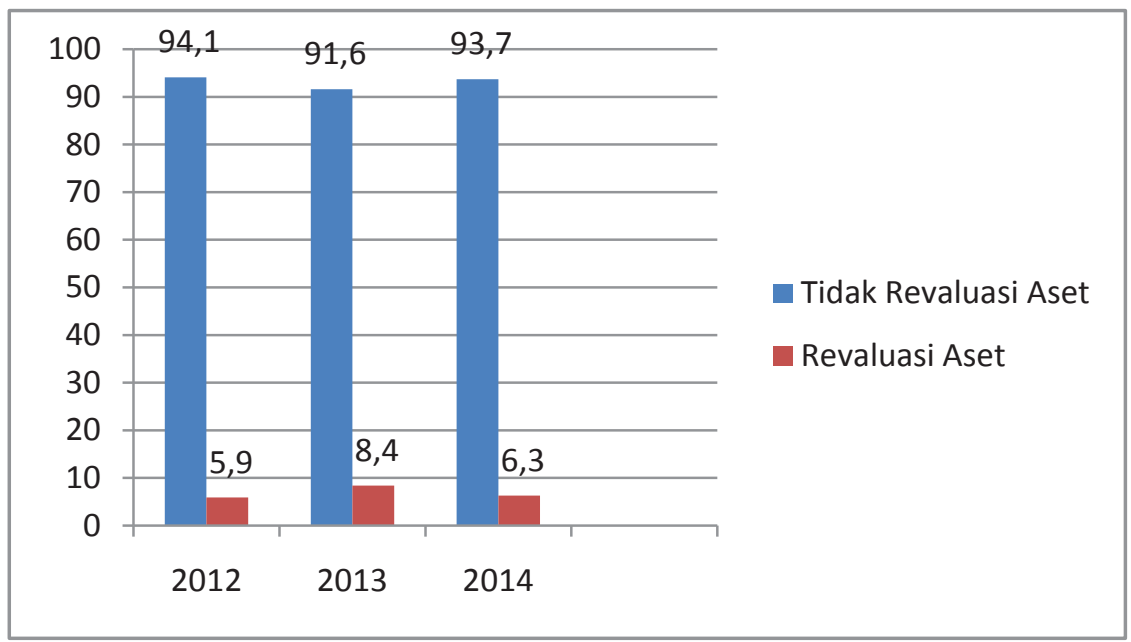

Sumber: Ahmar (2016).

\section{Gambar 1. Perkembangan Proporsi Perusahaan Manufaktur Tahun 2012-2014}

Berdasarkan gambar di atas maka terdapat perbedaan jumlah perusahaan dari tahun 2012 sampai dengan 2014. Hal ini disebabkan ada beberapa perusahaan yang delisting ataupun relisting dari Bursa Efek Indonesia yang diakses melalui www.idx.co.id. Perusahaan yang diteliti mulai tahun 2012 sejumlah 130 perusahaan, 2013 sejumlah 158 perusahaan, 2014 terdapat 146 perusahaan. Hasil pengamatan peneliti bahwa tahun 2012 perusahaan manufaktur yang melakukan revaluasi sebanyak $8(5.9 \%)$ dan yang tidak revaluasi sebanyak 122 (94.1\%), tahun 2013 yang melakukan revaluasi sebanyak $13(8.4 \%)$, dan yang tidak revaluasi $145(91.6 \%)$, tahun 2014 yang melakukan revaluasi sebanyak 10 (6.3\%) dan yang tidak revaluasi $136(93.7 \%)$.

Penelitian Lopes et al. (2012) melakukan penelitian revaluasi aset dan bagaimana hubungannya dengan kinerja perusahaan di masa mendatang jika terkait praktek good corporate governance (GCG). Secara empiris hasil penelitian menunjukkan revaluasi aset di Brazil dilakukan bukan untuk menyampaikan informasi kepada investor, tetapi untuk memperbaiki posisi ekuitas perusahaan. Begitu juga dengan GCG yang diproksikan dengan Brazilian Corporate Governance Index (BCGI) menunjukkan ketika BCGI tinggi maka tidak melakukan revaluasi, sebaliknya BCGI rendah perusahaan cenderung melakukan revaluasi aset. Hal ini fakta yang membuat pemerintah Brazil melarang perusahaan melakukan revaluasi aset.

Banyaknya pandangan negatif mengenai revaluasi aset bisa jadi disebabkan oleh reaksi emosional dan politikal selama dan setelah masa Great Depression yang diduga disebabkan oleh penyalahgunaan revaluasi aset pada tahun 1920-an sampai awal tahun 1930-an. Dillon (2015), menginvestigasi pengaruh revaluasi aset terhadap Great Depression yang terjadi pada tahun 1929-1939 di Amerika Serikat. Penelitian tersebut menunjukkan bahwa pada saat itu, perusahaan justru melakukan revaluasi aset untuk menurunkan nilai aset pada periode 1925-1934 (paralel dengan peristiwa Great Depression. Berdasarkan bukti yang ada, terlihat memanipulasi laba di periode tersebut. Konsep penerapan revaluasi aset dipandang dapat diterima, tetapi faktanya menunjukkan sebaliknya.

Pada umumnya masih belum terlalu banyak perusahaan di Indonesia yang menerapkan model revaluasi aset tetap. Penyebabnya di samping adanya tambahan biaya yang ditimbulkan atas perlakuan revaluasi yaitu biaya jasa penilai (appraiser) dan biaya audit karena semakin banyak item aset tetap yang diperiksa. Perkembangan status revaluasi aset perusahaan 
manufaktur per sektor dari tahun 2012 sampai dengan 2015 secara rinci ditunjukkan oleh tabel berikut:

Tabel 1. Perkembangan Penerapan Revaluasi Aset Per Sub Sektor Perusahaan Manufaktur Tahun 2012-2015

\begin{tabular}{|c|c|c|c|c|c|c|c|c|c|}
\hline \multirow{3}{*}{ NO } & \multirow{3}{*}{ SEKTOR } & \multicolumn{8}{|c|}{ TAHUN } \\
\hline & & \multicolumn{2}{|c|}{2012} & \multicolumn{2}{|c|}{2013} & \multicolumn{2}{|c|}{2014} & \multicolumn{2}{|c|}{2015} \\
\hline & & 1 & $\mathbf{0}$ & 1 & $\mathbf{0}$ & 1 & $\mathbf{0}$ & 1 & $\mathbf{0}$ \\
\hline 1 & Industri Dasar \& Kimia & 7 & 40 & 8 & 39 & 10 & 41 & 10 & 36 \\
\hline 2 & Aneka Industri & 4 & 24 & 4 & 23 & 4 & 24 & 4 & 20 \\
\hline \multirow[t]{2}{*}{3} & Industri Barang Konsumsi & 1 & 23 & 2 & 23 & 2 & 25 & 2 & 24 \\
\hline & Total & 12 & 87 & 14 & 85 & 16 & 90 & 16 & 80 \\
\hline
\end{tabular}

Sumber: DataIDX Annual Report (diolah kembali)

Pada tabel 1 di atas menjelaskan pada tahun 2012 perusahaan yang melakukan revaluasi aset yang ditunjukkan dengan status 1 sebanyak 12 perusahaan dan perusahaan yang tidak melakukan revaluasi dengan status 0 sebanyak 87 perusahaan. Berbeda dengan tahun 2013 sebagai pasca dari penerapan IFRS perusahaan yang melakukan revaluasi meningkat sebanyak 14 perusahaan dan yang tidak melakukan revaluasi 85 perusahaan. Sedangkan tahun 2014 dan 2015 perusahaan yang melakukan revaluasi memiliki kesamaan yaitu 16 perusahaan meningkat jika dibandingkan dengan tahun 2012 dan 2013.

Secara keseluruhan dari tiap-tiap sub sektor peningkatan jumlah perusahaan atas penerapan model revaluasi dikarenakan keuntungan yang didapat yakni bertambahnya nilai dari aset tetap perusahaan yang dinilai secara wajar (fair value). Hal tersebut berdampak terhadap permodalan dan pembiayaan untuk perusahaan. Jika dilihat secara total prosentase perusahaan yang melakukan dan yang tidak melakukan revaluasi aset tetap selama tahun 2012 sampai dengan 2015 adalah sebagai berikut:
Tabel 2. Prosentase Status Revaluasi Aset Tahun 2012-2015

\begin{tabular}{cccc}
\hline \multirow{2}{*}{ NO } & TAHUN & \multicolumn{2}{c}{ STATUS REVALUASI ASET } \\
\cline { 3 - 4 } & & $\mathbf{1}$ & $\mathbf{0}$ \\
\hline 1 & 2012 & $12.1 \%$ & $87.9 \%$ \\
2 & 2013 & $14.1 \%$ & $85.9 \%$ \\
3 & 2014 & $15.1 \%$ & $84.9 \%$ \\
4 & 2015 & $16.7 \%$ & $83.3 \%$ \\
\hline
\end{tabular}

Sumber: Data IDX Annual Report (diolah kembali)

Pada tabel 2 di atas menunjukkan bahwa perkembangan model revaluasi oleh perusahaan manufaktur di Indonesia dari tahun 2012 sampai dengan tahun 2015 mengalami peningkatan. Hal ini disebabkan salah satunya adanya fasilitas yang ditawarkan pemerintah terkait revaluasi aset tetap. Fasilitas pemerintah berdasarkan Peraturan Menteri Keuangan nomor 191/ PMK.010/2015 yang menjamin adanya insentif tarif $\mathrm{PPh}$ yang semula $10 \%$ menjadi lebih kecil yaitu, $3 \%, 4 \%$ atau $6 \%$ saja. Di samping dapat menjaga stabilitas ekonomi makro dan mendorong pertumbuhan ekonomi, model revaluasi diyakini meningkatkan nilai atas aset perusahaan, sehingga akhirnya kinerja keuangan dan laba yang diharapkan dapat tercapai.

Perkembangan kinerja keuangan di Indonesia dapat dipengaruhi oleh beberapa faktor baik yang berasal dari internal perusahaan maupun eksternal perusahaan. Dalam hal ini kinerja keuangan difokuskan dengan penerapan revaluasi aset. Kinerja keuangan dalam kaitannya 
dengan revaluasi aset diharapkan berpengaruh karena untuk melihat seberapa aktif aset yang dimiliki perusahaan dapat mendorong adanya revaluasi.

Penelitian mengenai kinerja keuangan perusahaan yang berhubungan dengan revaluasi aset sudah dilakukan oleh Kappa (2009), yang membuktikan secara empiris bahwa ROA dan ROI tidak berpengaruh signifikan terhadap revaluasi. Hal ini berbeda dengan penelitian yang dilakukan oleh Cheng dan Lin (2009) yang menunjukkan hasil empiris bahwa perusahaan dengan resiko yang tinggi cenderung menaikkan aset saat revaluasi. Penelitian lain juga dilakukan oleh Yao et al. (2014), yang membuktikan return on assets (ROA) dan debt to assets ratio (DAR) mempunyai hubungan yang signifikan negatif dan positif terhadap audit fees sebagai indikator dilakukannya revaluasi aset.

Sejauh ini di Indonesia belum banyak ditemukan penelitian mengenai revaluasi aset yang diatur dalam PSAK 16 yang diadopsi dari IAS 16 dan merupakan implementasi pasca pemberlakuan IFRS. Penelitian ini menganalisis perbedaan audit fees, kinerja keuangan perusahaan manufaktur yang dicerminkan dengan return on assets (ROA) dan debt to assets ratio (DAR) berdasarkan sektor industri pada perusahaan yang melakukan revaluasi aset. Pemilihan sektor manufaktur dan indikator kinerja keuangan perusahaan sebagai sampel mengacu pada penelitian Ahmar (2016), Kappa (2009), Yao et al. (2014), Cheng dan Lin (2009).

\section{Telaah Teori dan Pengembangan Hipotesis}

Peraturan Menteri Keuangan (PMK) nomor 191/PMK.010/2015 tentang penilaian kembali aktiva tetap untuk tujuan perpajakan bagi permohonan yang diajukan pada tahun 2015 dan 2016. Dalam PMK tersebut dijelaskan bahwa Wajib Pajak dapat melakukan penilaian kembali aktiva tetap untuk tujuan perpajakan dengan mendapatkan perlakuan khusus apabila permohonan penilaian kembali diajukan kepada Direktur Jenderal Pajak dalam jangka waktu sejak berlakunya Peraturan Menteri ini sampai dengan tanggal 31 Desember 2016 (http://www. pajak.go.id).

Perlakuan khusus yang dimaksud berupa Pajak Penghasilan yang bersifat final sebesar:

a. 3\% (tiga persen), untuk permohonan yang diajukan sejak berlakunya Peraturan Menteri Keuangan sampai dengan tanggal 31 Desember 2015.

b. $4 \%$ (empat persen), untuk permohonan yang diajukan sejak 1 Januari 2016 sampai dengan 30 Juni 2016.

c. $6 \%$ (enam persen), untuk permohonan yang diajukan sejak 1 Juli 2016 sampai dengan 31 Desember 2016.

Tarif tersebut dikenakan atas selisih lebih aktiva tetap hasil penilaian kembali atau hasil perkiraan penilaian kembali oleh Wajib Pajak, di atas nilai sisa buku fiskal semula. Wajib Pajak yang berhak mengajukan permohonan meliputi: Wajib Pajak badan dalam negeri, Bentuk Usaha Tetap (BUT), dan Wajib Pajak orang pribadi yang melakukan pembukuan, termasuk:

a. Wajib Pajak yang menyelenggarakan pembukuan dengan Bahasa Inggris dan satuan mata uang Dollar Amerika Serikat.

b. Wajib Pajak yang masih berada dalam jangka waktu 5 tahun sejak dilakukannya penilaian kembali terakhir berdasarkan PMK 79/PMK.03/2008.

Peraturan Menteri Keuangan nomor 191/ PMK.010/2015 tentang penilaian kembali aktiva tetap untuk tujuan perpajakan bagi permohonan yang diajukan pada tahun 2015 dan 2016 diharapkan dapat meningkatkan penerapan revaluasi aset dari emiten yang sebelumnya tidak menerapkan model tersebut. Hal ini dikarenakan terdapat perlakuan khusus akan diberikan kepada Wajib Pajak berupa pengenaan PPH final sebesar: (a) 3\% (tiga persen), untuk permohonan yang diajukan sejak 20 Oktober 2015 s.d. 31 Desember 2015, (b) 4\% (empat persen), untuk permohonan yang diajukan sejak 1 Januari 2016 s.d. 30 Juni 2016, (c) 6\% (enam persen), untuk 
permohonan yang diajukan sejak 1 Juli 2016 s.d. 31 Desember 2016.

Menurut Dewi (2014), (1) apabila secara fiskal perusahaan mengalami kerugian, maka sebaiknya perusahaan melakukan revaluasi atas aset tetapnya, karena dalam pembayaran pajak perusahaan akan lebih diuntungkan, (2) jika secara fiskal perusahaan mengalami laba, maka revaluasi atas aset tetapnya dilakukan saja, walaupun dalam pembayaran pajak perusahaan akan mengalami kerugian, akan tetapi pada tahun berikutnya setelah dilakukan revaluasi atas aset perusahaan maka perusahaan akan lebih menghemat pajak.

Ahmar (2016) mengemukakan secara logis apabila nilai atas aset semakin tinggi maka berdampak terhadap peningkatan kepercayaan bagi pengguna laporan keuangan. Penyajian laporan keuangan dengan nilai wajar (fair value) diharapkan mampu meningkatkan kualitas informasi akuntansi yang dikonsumsi oleh pengguna laporan keuangan secara luas.

Penelitian ini dikembangkan dari penelitian-penelitian sebelumnya. Menurut hasil penelitian Yao et al. (2014), Dimitropoulos et al. (2013), Ettredge et al. (2013), Brown et al. (1992), Bryce et al. (2014) menunjukkan hasil yang signifikan hubungan antara revaluasi aset dengan biaya audit (audit fees). Hasil yang berbeda didapatkan dari penelitian Goncharov et al. (2012) yang mengungkapkan bahwa revaluasi aset tidak memiliki hubungan yang signifikan terhadap audit fees. Jika dilihat dari aspek kinerja keuangan perusahaan, menurut Aboody et al. (1999), Dimitropoulos et al. (2013), Yao et al. (2014) penelitiannya menunjukkan bahwa revaluasi aset berhubungan signifikan terhadap return on assets (ROA). Sedangkan hasil yang berbeda didapat oleh Kappa (2009). Untuk aspek leverage, hasil penelitian Yao et al. (2014), Andison (2015), Franck Missonier-Piera (2007), mengungkapkan revaluasi aset memiliki hubungan yang signifikan terhadap leverage dalam diproksikan dengan debt to assets ratio (DAR). Sedangkan hasil yang berbeda ditemukan oleh Yulistia dkk. (2014), Courtenay et al. (2004).

Berbagai penelitian telah dilakukan untuk melihat hubungan antara revaluasi aset dan audit fees. Dari hasil penelitian Yao et al. (2014), Dimitropoulos et al. (2013), Ettredge et al. (2013), Brown et al. (1992), Bryce et al. (2014) menunjukkan adanya signifikansi hubungan antara revaluasi aset dengan biaya audit (audit fees). Secara tidak langsung ketika perusahaan menetapkan penilaian atas asetnya menggunakan revaluation model, seharusnya peningkatan biaya audit atas jasa auditor independen yang dibebankan kepada perusahaan bukan menjadi alasan takut dalam melakukan revaluasi aset. Hal tersebut akan dapat ditutup dengan keuntungan atas kenaikan nilai wajar aset tersebut. Dari hal tersebut maka dirumuskan hipotesis sebagai berikut:

H1: Terdapat perbedaan audit fees berdasarkan sektor industri pada perusahaan yang melakukan revaluasi aset.

Hasil penelitian Aboody et al. (1999), Dimitropoulos et al. (2013), Yao et al. (2014) penelitiannya menunjukkan bahwa revaluasi aset berhubungan signifikan terhadap return on assets (ROA). Perusahaan yang memiliki keunggulan kompetitif dibandingkan pesaing, maka perusahaan tersebut memiliki peluang untuk meningkatkan laba bersih. Laba bersih diperoleh perusahaan dari jumlah pendapatan dikurangi dengan beban perusahaan. Peningkatan laba bersih perusahaan dipengaruhi oleh penggunaan secara efisien pada aset perusahaan. Dengan memfokuskan pada laba bersih dan pengelolaan atas aset emiten secara efisien maka nilai return on assets akan meningkat. Berdasarkan penjelasan di atas maka hipotesis yang diajukan sebagai berikut:

$\mathrm{H} 2$ : Terdapat perbedaan return on assets (ROA) berdasarkan sektor industri pada perusahaan yang melakukan revaluasi aset.

Leverage yang diwakili oleh debt to assets ratio (DAR) menggambarkan seluruh aset perusahaan dan risiko keuangan yang akan 
menjadi beban perusahaan di masa yang akan datang yang pada akhirnya akan mempengaruhi pendapatan. Rasio leverage akan menjadi pertimbangan bagi emiten dalam melakukan revaluasi aset tetap atau tidak. Berdasar uraian di atas maka hipotesis yang diajukan sebagai berikut:

H3: Terdapat perbedaan debt to assets ratio (DAR) berdasarkan sektor industri pada perusahaan yang melakukan revaluasi aset.

\section{Metode}

Penelitian ini bertujuan untuk menganalisis perbedaan audit fees, return on assets dan debt to assets ratio berdasarkan sektor industri pada perusahaan yang melakukan revaluasi aset. Menurut Ghozali (2016:3), tujuan dari analisis data adalah mendapatkan informasi relevan yang terkandung di dalam data penelitian dan menggunakan hasilnya untuk memecahkan suatu masalah. Data dari ketiga variabel terikat yaitu audit fees, ROA dan DAR dianalisis dengan uji normalitas untuk mengetahui apakah data tersebut berdistribusi normal atau tidak (Ghozali, 2016:154).

Variabel dependen dan independen dalam penelitian ini diuraikan sebagai berikut:

Tabel 3. Operasionalisasi Variabel

\begin{tabular}{|c|c|c|c|c|}
\hline $\begin{array}{c}\text { Variabel/Sub } \\
\text { Variabel }\end{array}$ & Indikator & Ukuran & Skala & Rujukan \\
\hline Audit Fees & Professional fees & Nilai Professional fees & Rasio & Goncharov,et al (2011) \\
\hline Kinerja Keuangan & $\begin{array}{c}\text { Return On Assets } \\
\text { (ROA) }\end{array}$ & $\frac{\text { EBIT }}{\text { Total Aktiva }} \times 100 \%$ & Rasio & Yao et al (2014) \\
\hline $\begin{array}{c}\text { Risiko/Leverage } \\
\text { Peusahaan }\end{array}$ & $\begin{array}{c}\text { Debt to Assets Ratio } \\
\text { (DAR) }\end{array}$ & $\frac{\text { Total utang }}{\text { Total aktiva }} \times 100 \%$ & Rasio & Yao et al (2014) \\
\hline Revaluasi Aset Tetap & Financial Statement & $\begin{array}{l}1 \text { Jika item tersebut } \\
\text { dilakukan oleh emiten }\end{array}$ & Nominal & Yao et al (2014) \\
\hline
\end{tabular}

Sumber: Jurnal penelitian sebelumnya.

Metode yang dipakai dalam penelitian ini adalah menggunakan uji Kruskal-Wallis Test yang merupakan alat uji statistik non parametrik yang sangat berguna untuk menentukan apakah $\mathrm{k}$ sampel independen berasal dari populasi yang berbeda (Ghozali, 2015:176). Uji KruskalWallis menguji hipotesis nol bahwa $\mathrm{k}$ sampel berasal dari populasi yang sama atau populasi identik dengan median yang sama.

\section{Hasil Penelitian dan Pembahasan}

Subyek penelitian ini menggunakan populasi perusahaan secondary manufacture yang terdaftar di Bursa Efek Indonesia yang melaporkan keuangannya pada periode tahun 2012-2015 serta menggunakan data seluruh perusahaan publik yang diakses melalui $w w w$. $i d x . c o . i d$. Perincian data yang digunakan untuk penelitian ini dapat diuraikan sebagai berikut:

Tabel 4. Pemilihan Sampel Penelitian

\begin{tabular}{lccccc}
\hline \multicolumn{1}{c}{ Sampel } & \multicolumn{4}{c}{ Tahun } & \multirow{2}{*}{ Total } \\
\cline { 2 - 5 } & 2012 & 2013 & 2014 & 2015 & \\
\hline Jumlah sampel perusahaan manufaktur yang terdaftar & $\mathbf{1 4 3}$ & $\mathbf{1 4 3}$ & $\mathbf{1 4 3}$ & $\mathbf{1 4 3}$ & $\mathbf{5 7 2}$ \\
di BEI & & & & & \\
Eliminasi : Data perusahaan yang tidak lengkap & $(44)$ & $(44)$ & $(37)$ & $(47)$ & $(172)$ \\
Data Tahap 1 : & $\mathbf{9 9}$ & $\mathbf{9 9}$ & $\mathbf{1 0 6}$ & $\mathbf{9 6}$ & $\mathbf{4 0 0}$ \\
Eliminasi : Data perusahaan yang tidak melakukan revaluasi aset & $(73)$ & $(70)$ & $(75)$ & $(64)$ & $(282)$ \\
Data sampel final & $\mathbf{2 6}$ & $\mathbf{2 9}$ & $\mathbf{3 1}$ & $\mathbf{3 2}$ & $\mathbf{1 1 8}$ \\
\hline
\end{tabular}

Sumber: Data sekunder yang diolah. 
Berdasarkan seleksi sampel pada tabel 4 di atas dapat dijelaskan bahwa jumlah sampel awal pada perusahaan secondary manufacture yang terdaftar di Bursa Efek Indonesia (BEI) periode tahun 2012-2015 secara keseluruhan tiap tahun jumlahnya sama masing-masing 143 perusahaan, sehingga total seluruh sampel awal periode pengamatan sebanyak 572 perusahaan. Selanjutnya terdapat eliminasi tahap awal untuk data perusahaan yang tidak lengkap, sehingga diperoleh total perusahaan menjadi 400 . Eliminasi kedua untuk data perusahaan yang tidak melakukan revaluasi aset, sehingga data sampel final menjadi 118 perusahaan.

Penelitian ini menggunakan objek pada perusahaan manufaktur di Bursa Efek Indonesia (BEI) periode amatan 2012-2015. Data yang digunakan dalam penelitian ini adalah data sekunder berupa laporan keuangan perusahaan, kinerja keuangan perusahaan dan laporan tahunan perusahaan yang mempunyai komponen OCI (Other Comprehensive Income) serta terdapat akun revaluasi aset tetap. Tujuan dari penelitian ini adalah untuk menganalisis perbedaan audit fees, ROA dan DAR berdasarkan sektor industri pada perusahaan yang melakukan revaluasi aset.

Sehubungan dengan diberlakukannya standar akuntansi berbasis IFRS, maka salah satu bahasan yang sedang berkembang adalah adanya penerapan revaluasi aset. Revaluasi aset merupakan aktivitas dalam akuntansi untuk menilai kembali aset tetap perusahaan yang berdampak terhadap laba yang dilaporkan dalam laporan laba rugi komprehensif. Berdasarkan pengamatan beberapa tahun jika dilihat dari laporan keuangan perusahaan khususnya terdapat pada komponen other comprehensive income (OCI), penerapan penilaian kembali aset tetap (revaluasi aset) masih sedikit jumlahnya. Sebenarnya model revaluasi sangat baik jika diterapkan karena dapat meningkatkan kualitas informasi keuangan.

Berdasarkan hasil uji normalitas yang telah dilakukan menunjukkan bahwa data tidak berdistribusi normal untuk variabel audit fees,
ROA dan DAR. Hasil pengujian selanjutnya menggunakan uji beda Kruskal-Wallis Test. Hasil uji beda dengan Kruskal-Wallis Test menunjukkan bahwa terdapat perbedaan signifikansi berdasarkan sektor industri pada perusahaan yang melakukan revaluasi aset. Selanjutnya ditemukan hasil yang sama terdapat perbedaan signifikansi berdasarkan sektor industri pada perusahaan yang melakukan revaluasi aset untuk variabel audit fees, ROA dan DAR untuk keseluruhan perusahaan amatan pada tahun 2012-2015.

\section{Perbedaan Audit Fees Berdasarkan Revaluasi Aset}

Audit fees merupakan pendapatan yang besarannya bervariasi tergantung dari jenis penugasan audit seperti ukuran perusahaan klien, kompleksitas jasa audit serta nama KAP yang melakukan jasa audit (www.ahlibaca. com). Audit fees biasanya diterima oleh seorang akuntan publik setelah melaksanakan jasa auditnya, besarnya tergantung dari resiko penugasan. Fee yang besar dapat membuat kantor akuntan sulit menolak kehendak klien dan fee yang kecil dapat menyebabkan waktu dan biaya pelaksanaan prosedur audit terbatas.

Berdasarkan pengujian uji beda KruskalWallis Test untuk menguji variabel audit fees diperoleh hasil bahwa $\mathrm{HO}$ ditolak atau terdapat perbedaan signifikansi berdasarkan sektor industri pada perusahaan yang melakukan revaluasi aset pada periode amatan 20122015. Penelitian ini konsisten dengan hasil penelitian Yao et al. (2014), Dimitropoulos et al. (2013), Ettredge et al. (2013), Brown et al. (1992), Bryce et al. (2014) menunjukkan hasil yang signifikan hubungan antara revaluasi aset dengan biaya audit (audit fees). Berbeda dengan hasil penelitian oleh Goncharov et al. (2012) yang mengungkapkan bahwa revaluasi aset tidak memiliki hubungan yang signifikan terhadap auditfees. 


\section{Perbedaan ROA Berdasarkan Revaluasi Aset}

Kinerjakeuanganmerupakansuatugambaran mengenai kondisi keuangan perusahaan yang dianalisis dengan dengan alat analisis keuangan. Menurut Fahmi (2011: 2) kinerja keuangan adalah suatu analisis yang dilakukan untuk melihat sejauh mana suatu perusahaan telah melaksanakan dengan menggunakan aturanaturan pelaksanaan keuangan secara baik dan benar. Rasio profitabilitas adalah sekelompok rasio yang memperlihatkan pengaruh gabungan dari likuiditas, manajemen aktiva, dan hutang terhadap hasil operasi (Brigham dan Houston, 2001:89). Secara konseptual ROA adalah rasio laba bersih terhadap total aktiva, tapi laba di sini adalah laba sebelum pajak bunga dan pajak atau EBIT terhadap rata-rata aktiva.

Berdasarkan pengujian uji beda KruskalWallis Test untuk menguji variabel ROA diperoleh hasil bahwa H0 ditolak atau terdapat perbedaan signifikansi berdasarkan sektor industri pada perusahaan yang melakukan revaluasi aset pada periode amatan 20122015. Penelitian ini konsisten dengan hasil penelitian Aboody et al. (1999), Dimitropoulos et al. (2013), Yao et al. (2014) penelitiannya menunjukkan bahwa revaluasi aset berhubungan signifikan terhadap Return On Assets (ROA). Sedangkan hasil yang berbeda didapat oleh Ross (2009).

\section{Perbedaan DAR Berdasarkan Revaluasi Aset}

Rasio leverage atau yang disebut dengan raiso pembiayaan dengan utang, memiliki tiga implikasi penting: (1) memperoleh dana melalui utang membuat pemegang saham dapat mempertahankan pengendalian atas perusahaan dengan investasi yang terbatas, (2) kreditur melihat ekuitas, atau dana yang disetor pemilik, untuk memberikan marjin pengaman, sehingga jika pemegang saham hanya meberikan sebagian kecil dari total pembiayaan, maka risiko perusahaan sebagian besar ada pada kreditur, (3) jika perusahaan memperoleh pengembalian yang lebih besar atas investasi dibiayai dengan dana pinjaman dibanding pembayaran bunga, maka pengembalian atas modal pemilik akan lebih besar atau leveraged (Brigham dan Houston, 2001:84). Debt To Assets Ratio (DAR) memberikan beberapa indikasi mengenai kemampuan perusahaan untuk menahan kerugian tanpa merusak ketertarikan para kreditor. Semakin besar persentase utang terhadap total aset, semakin besar risiko perusahaan tidak dapat melunasi kewajibannya yang akan jatuh tempo.

Berdasarkan pengujian uji beda KruskalWallis Test untuk menguji variabel DAR diperoleh hasil bahwa H0 ditolak atau terdapat perbedaan signifikansi berdasarkan sektor industri pada perusahaan yang melakukan revaluasi aset pada periode amatan 2012-2015. Penelitian ini konsisten dengan hasil penelitian Yao et al. (2014), Andison (2015), Piera (2007), mengungkapkan revaluasi aset memiliki hubungan yang signifikan terhadap leverage dalam diproksikan dengan debt to assets ratio (DAR). Sedangkan hasil yang berbeda ditemukan oleh Yulistia dkk. (2014), Courtenay et al. (2004).

\section{Simpulan, Keterbatasan dan Implikasi Hasil Penelitian}

Tujuan penelitian ini adalah untuk melihat apakah terdapat perbedaan dalam Audit Fees, Return On Assets (ROA) dan Debt to Assets Ratio (DAR) antara perusahaan manufaktur di Indonesia yang melakukan revaluasi aset jika dilihat berdasarkan tiap sektor industri. Berdasarkan hasil pengujian dan analisis data yang dilakukan, dapat diambil kesimpulan sebagai berikut:

1. Terdapat perbedaan signifikansi audit fees berdasarkan sektor industri pada perusahaan yang melakukan revaluasi aset.

2. Terdapat perbedaan signifikansi ROA berdasarkan sektor industri pada perusahaan yang melakukan revaluasi aset.

3. Terdapat perbedaan signifikansi DAR berdasarkan sektor industri pada perusahaan yang melakukan revaluasi aset. 
Berdasarkan hasil penelitian, maka yang dapat diberikan untuk riset mendatang dapat menguji menggunakan variabel lain seperti total aset, ukuran perusahaan, DER (Debt to Equity Ratio), dan return saham yang erat kaitannya dengan revaluasi aset. Penelitian lebih lanjut dapat menguji secara empiris perusahaan selain manufakur yaitu perbankan dan menggunakan sampel yang lebih banyak. Pengujian ulang juga dapat dilakukan dengan didukung Peraturan Menteri Keuangan (PMK) nomor 191/ PMK.010/2015 tentang penilaian kembali aktiva tetap untuk tujuan perpajakan bagi permohonan yang diajukan tahun 2015 dan 2016. Diharapkan kebijakan ekonomi seperti ini bisa diterapkan di tahun-tahun selanjutnya agar perusahaan bisa rutin melakukan revaluasi aset. Perusahaan khususnya bagian keuangan mengingat revaluasi aset dapat menggambarkan kondisi sesungguhnya, maka diharapkan perusahaan dapat menerapkan pilihan model revaluasi aset daripada historical cost.

\section{Daftar Referensi}

Aboody, D., Barth, M. E., \& Kasznik, R. 1999. Revaluations of fixed assets and future firm performance: Evidence from the UK. Journal of Accounting and Economics, 26(1), 149-178.

Ahmar, N. 2016. Investigasi Atas Revaluasi Aset, Penyajian Laporan Keuangan, Dan Kualitas Auditor Berbasis Mandatory IFRS. Seminar Nasional dan Doctoral Colloquioum, Universitas Trisakti, 2-13.

Andison. 2015. Fixed Asset Revaluation: Market Reactions. Simposium Nasional Akuntansi 18 Universitas Sumatera Utara, Medan, 10-13.

Brown, P., Izan, H. Y., \& Loh, A. L. 1992. Fixed asset revaluations and managerial incentives. Abacus, 28(1), 36-57.

Bryce, M., Ali, M. J., \& Mather, P. R. 2014. Accounting quality in the pre-/post-IFRS adoption periods and the impact on audit committee effectiveness-Evidence from
Australia. Pacific-Basin Finance Journal, 35, 163-181.

Brigham, E. F, Houston, J.F. 2001. Manajemen Keuangan. Erlangga. Jakarta.

Cheng, C. S. A., \& Lin, S. W. J. 2009. When do firms revalue their assets upwards? Evidence from the UK. International Journal of Accounting and Information Management. 17(2000). 166-188.

Courtenay, S. M., \& Cahan, S. F. 2004. The impact of debt on market reactions to the revaluation of noncurrent assets. PacificBasin Finance Journal, 12(2), 219-243.

Dewi, P. 2014. Implementasi Revaluasi Aset Tetap Berdasarkan Peraturan Menteri Keuangan No. 79 Thun 2008 Pada Perusahaan di Indonesia. Jurnal Akuntansi Unesa. Vol 2, No 2, 18-19.

Dillon, G. J. (1979). Academy of Accounting Historians, 6(1), 1-15.

Dimitropoulos, P. E., Asteriou, D., Kousenidis, D., \& Leventis, S. 2013. The impact of IFRS on accounting quality: Evidence from Greece. Advances in Accounting, 29(1), 108-123.

Ettredge, M., Xu, Y., Yi, H. 2013. Fair Value Measurements and Audit Fees: Evidence from the Banking Industry. Auditing. 33, 33-58.

Fahmi I. 2011. Manajemen Investasi: Teori dan Soal Jawab. Salemba Empat. Jakarta.

Friskianti, Y. 2014, Kualitas Informasi Akuntansi Pra Dan Pasca Adopsi IFRS, Accounting Analysis Journal, 3(4), 543-552.

Ghozali, I. 2016. Aplikasi Analisis Multivariate dengan program IBM SPSS 23 Edisi Delapan. $\quad$ Semarang: Universitas Dipenogoro.

Ghozali, I. 2002. Statistik Non Parametrik. Semarang: Universitas Dipenogoro.

Goncharov, I, Edward J. R, and Thorsten S. 2012. "Fair value and audit fees." Review of Accounting Studies 19.1: 210-241.

Hastoni, H. 2013. Model Revaluasi Aset Tetap dan Penerapannya pada Perusahaan Go 
Public. Jurnal Dosen STIE Kesatuan, 1-5. Kappa, A. 2009. Analisis Hubungan Revaluasi Aktiva Tetap Dengan Return On Investment (ROI) dan Return On Assets (ROA), 55-57. Lopes, A. B., Walker, M. 2012. Asset revaluations, future firm performance and firm-level corporate governance arrangements: New evidence from Brazil, British Accounting Review, 44(2), 53-67.

Missonier-Piera, F. 2007. Motives for fixedasset revaluation: An empirical analysis with Swiss data. The International Journal of Accounting, 42(2), 186-205.
Tersedia di http://www.pajak.go.id. Diakses pada 14 Juli 2016. Pukul 19.09 WIB.

Yao, D. (Troy), Percy, M., \& Hu, F. 2014. Fair value accounting for non-current assets and audit fees: evidence from Australian companies. Journal of Contemporary Accounting \& Economics, 11(1), 31-45.

Yulistia, R. Fauziati, P. Minovia, A. Khairati, A. 2014. Pengaruh Leverage, Arus Kas Operasi, Ukuran Perusahaan dan Fixed Asset Intensity Terhadap Revaluasi Aset. Simposium Nasional Akuntansi 18 Universitas Sumatera Utara, Medan, 1115. 